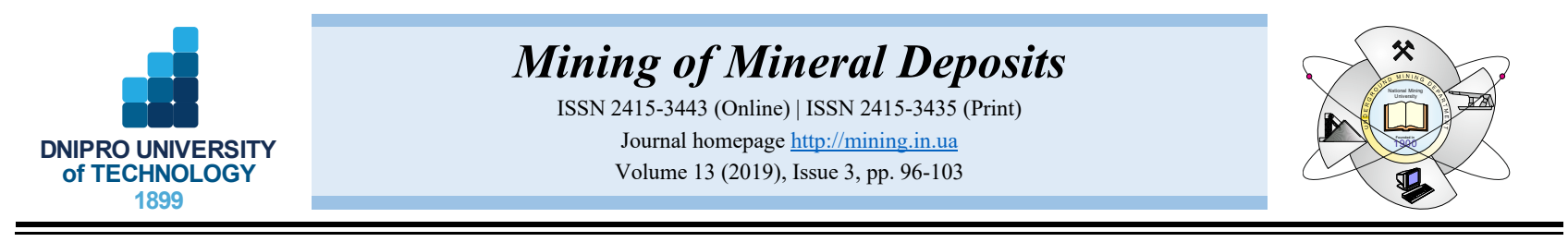

UDC 622.272: 622.6: 622.807

https://doi.org/10.33271/mining13.03.096

\title{
INVESTIGATION OF THE DUST FORMATION PROCESS WHEN HOISTING THE URANIUM ORES WITH A BUCKET
}

\author{
M. Stupnik ${ }^{1}$, V. Kalinichenko ${ }^{1 *}$, M. Fedko ${ }^{1}$, O. Kalinichenko ${ }^{1}$, V. Pukhalskyi ${ }^{2}$, B. Kryvokhin ${ }^{2}$ \\ ${ }^{1}$ Kryvyi Rih National University, Kryvyi Rih, Ukraine \\ ${ }^{2} S E$ "Eastern Ore Dressing Complex” (SE “VostGOK”), Zhovti, Vody, Ukraine \\ *Corresponding author: e-mail vsevolod921@mail.ru, tel.+380675682260
}

\begin{abstract}
Purpose. Determining the possible level of air dustiness during the bucket hoisting of uranium ores along the shaft "Holovnyi" of the mine "Novokostiantynivska", SE "VostGOK".

Methods. To determine the level of air dustiness, a physical modelling of this process under laboratory conditions was used. Physical modelling of the dust formation process has been performed on a laboratory bench, which consisted of an AT-2K-250/500 wind tunnel with non-return-flow and a closed working section, as well as an aspirator with a drive and hoses for sampling and filtration of air. The granulometric composition has been determined for modelling: the parameters of large-sized fractions - by the linear method (i.e., measurements of the geometric dimensions of the separate pieces and their weighting), and the composition of fine-sized fractions $(-15+0 \mathrm{~mm})-$ by sieve analysis and weighing.
\end{abstract}

Findings. The granulometric composition of the rock mass has been determined, which is planned to get out by a bucket hoisting method along the shaft "Holovnyi", and the dust formation process has been modelled on a laboratory bench. It has been set that the level of air dustiness during the rock mass hoisting will be significantly influenced by its humidity or the additional binding of ore fines in the upper layer if to treat the surface with acting agents. Moreover, it is influenced by the uniformity of these fines distribution within the bucket volume, which, in turn, will depend on the way of its loading. It is recommended to use the vibrating feeder for loading the bucket. Thus, the sufficient natural moisture of the rock mass (more than 4\%) will ensure the level of dust content of the emitted air below the normative indicators.

Originality. It has been determined that the dust content in the air depends on the moisture of the rock mass and the presence of moisture in the ore to more than $4 \%$ reduces the level of dust in the air to $0.4-0.45 \mathrm{mg} / \mathrm{m}^{3}$, which is $0.67-0.75$ of the existing safe dust concentration for such conditions.

Practical implications. The result obtained confirms the possibility of using the bucket hoisting method along the shaft "Holovnyi" to the daylight surface of uranium ores mined at the mine "Novokostiantynivska" (provided that the proposed recommendations will be observed) without exceeding the existing safe dust concentration of air supplied to the mine.

Keywords: bucket hoisting, dust content, air, measures for dust suppression, ore

\section{INTRODUCTION}

The mine "Novokostiantynivska" is part of the SE "Eastern Ore Dressing Complex" (SE "VostGOK"), and is the largest in Europe in terms of uranium resources (Kolosov, Stupnik, \& Kalinichenko, 2014). The field is uncovered by three shafts: shafts "Holovnyi", "Rozviduvalno-Ekspluatatsiinyi \#6", "Ventyliatsiinyi-1". On an industrial scale the uranium ore has been extracted at this mine since 2011. The ore deposits mining is carried out in the depth range from 180 to $300 \mathrm{~m}$. The rated output of the start-up facility at the mine "Novokostiantynivska" is about 250 thousand tons per year with a total rated output of 1500 thousand tons. The existing volumes of uranium ore mining are limited by the hoisting capabilities of the "Rozviduvalno-Ekspluatatsiinyi $\# 6$ " and "Ventyliatsiinyi-1" shafts, which now produce to about 330 thousand tons of rock mass per year.

One possibility to increase the volumes of uranium ore mining at this mine is the use of the shaft "Holovnyi" in the bucket-type hoisting of the mined ore to the daylight surface, Figure 1.

(C) 2019. M. Stupnik, V. Kalinichenko, M. Fedko, O. Kalinichenko, V. Pukhalskyi, B. Kryvokhin. Published by the Dnipro University of Technology on behalf of Mining of Mineral Deposits. This is an Open Access article distributed under the terms of the Creative Commons Attribution License (http://creativecommons.org/licenses/by/4.0/),

which permits unrestricted reuse, distribution, and reproduction in any medium, provided the original work is properly cited. 


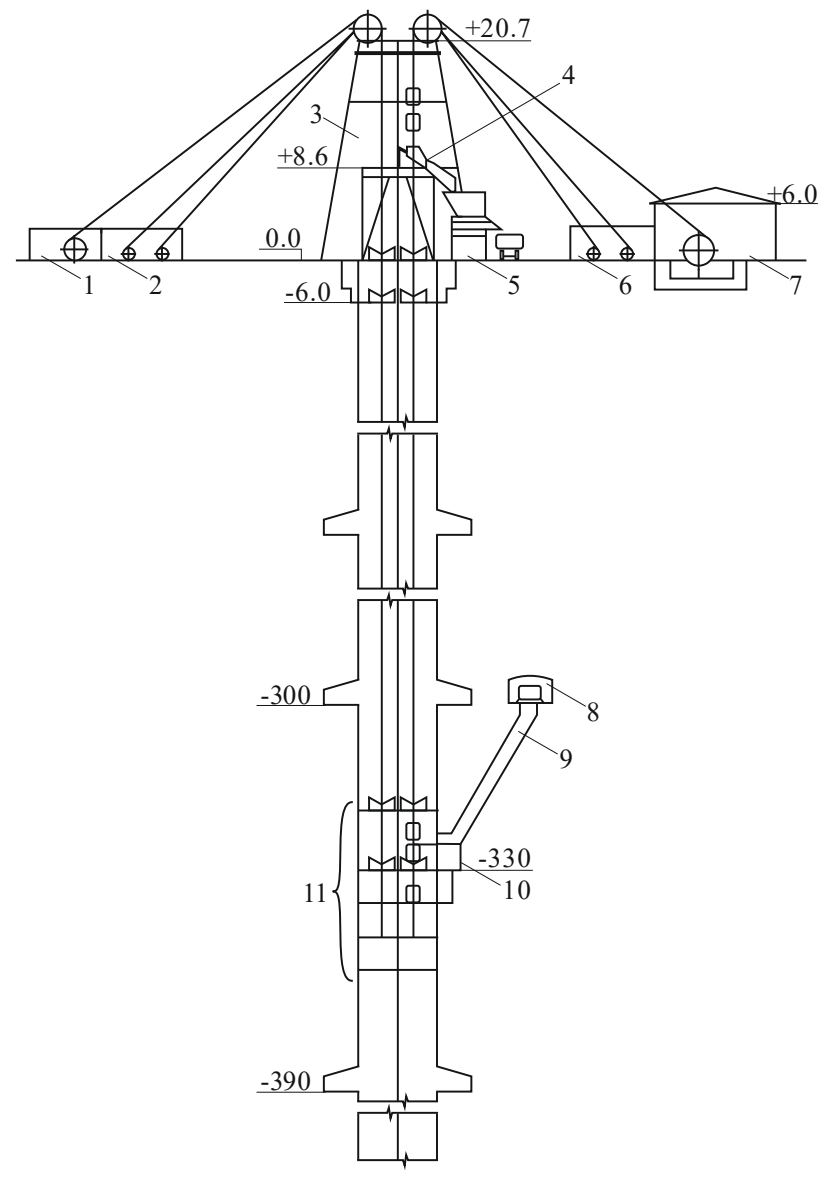

Figure 1. Scheme of hoisting the ore by a bucket to the daylight surface along the shaft "Holovnyi": 1 - hoisting machine MPSH-6.3; 2 -building for winches \#2; 3 -winding tower; 4 -complex for bucket unloading; 5-complex for bucket loading; 6 -building for winches \#1; 7-building for hoisting machine TS3.5 $\times 2 A ; 8$-chamber for swing tipping device; 9 -gravity ore pass; 10 -complex for bucket loading; 11 - rigid reinforcement stage

However, this shaft is used as an air intake shaft for airing the mining operations at this mine, and therefore there is a problem of dust accumulation in the fresh air, which will be blown off from the bucket surface during its hoisting. Furthermore, the permissible level of air dustiness is specified by the current safety norms (Safety rules..., 2017), according to which the dust content in the air supplied to the mine and to workplaces should not exceed $30 \%$ of its maximum permissible concentration (MPC). With the existing dust MPC of $2 \mathrm{mg} / \mathrm{m}^{3}$ (for uranium ores containing from 10 to $70 \%$ free silica), the norm of air dustiness for such conditions is $0.6 \mathrm{mg} / \mathrm{m}^{3}$. The increased air dustiness that may arise violate the requirements of safety norms and may be a potential source of occupational diseases caused by this factor.

In case of exceeding the permissible level of air dustiness, the measures for dust suppression can be taken by way of additional moistening the rock mass surface, as it is recommended in (Gurin, Beresnevich, Nemchenko, \& Oshmyansky, 2007; Tkachuk, Tkachuk, \& Gurin, 2011), or by treatment with Surface Acting Agents (SAA, surfactants). The use of surfactants improves wetting ability of dust particles and increases the duration of this effect, as a result of which surfactants are widely used in many mining enterprises of Ukraine (Bondarenko, Svietkina, \& Sai, 2017). High efficiency, confirmed by practical experience, is evidenced by the use of some aqueous solutions of chlorides, in particular bischofite (Nesterenko, 2001; Nesterenko, 2008), which is a weak electrolyte solution and provides high capillary dust autoadhesion, that is, the binding (adhesion) of dust particles and their adhesion to larger particles. Therewith, to achieve maximum efficiency of binding the small particles, the density of such a solution, according to the recommendations set out in (Nesterenko, 2008), should be not less than $1170 \mathrm{~kg} / \mathrm{m}^{3}$, and the specific consumption should be $0.5-1.0$ litres per $1 \mathrm{~m}^{2}$ of the surface to be treated. In our case, this will prevent their blowing off from the surface of loaded bucket with oncoming air flow and will contribute to a significant decrease in air dustiness.

The main purpose of the work is to determine the possible dust level of the supplied air when using the shaft "Holovnyi" for hoisting the rock mass with a bucket and, if it is exceeded, to develop the measures that will reduce the dust content in the air to the current norms.

In the course of the research, it was planned to solve the following tasks:

- to determine the granulometric composition of the rock mass to be hoisted to the surface in order to establish the quantitative content of fine particles in it, which will be a potential source of dust formation during the bucket hoisting;

- to study the dust formation process during the hoisting the rock mass with a bucket under laboratory conditions and set the influence of the uniformity of ore fines distribution throughout the volume of the bucket and the ore moisture on the level of air dustiness;

- to develop measures for reducing the level of dust content in the air and bring it to current norms in case of exceeding permissible level of air dustiness.

\section{METHODS}

For modelling the dust formation process, primarily, it is necessary to know the amount of fine-sized fractions contained in the rock mass. The amount of fine-sized fractions, in turn, depends on the parameters of breaking the uranium ores massif (Khomenko \& Maltsev, 2013; Stupnik, Kalinichenko, Fedko, \& Mirchenko, 2013a; Stupnik, Kalinichenko, Fedko, \& Mirchenko, 2013b). There is no doubt that the parameters of drilling and blasting operations depend on the geological structure of the massif and its stress-strain state (Khomenko, Sudakov, Malanchuk, \& Malanchuk, 2017; Lozynskyi, Saik, Petlovanyi, Sai \& Malanchuk, 2018; Stupnik, Kalinichenko, Fedko, \& Kalinchenko, 2018; Stupnik, Kalinichenko, \& Kalinichenko, 2018), the technology of development and face-entry drivages (Bondarenko, Kovalevs'ka, \& Fomychov, 2012; Khomenko, 2012; Vladyko, Kononenko, \& Khomenko, 2012; Kovalevs'ka, Symanovych, \& Fomychov, 2013), as well as the stope works performance (Pismennyi, 2014; Tarasyutin, 2015; Pysmennyi et al., 2018; Malanchuk, 2019). Thus, the quality of ore breakage plays a key role in the ore segregation and in the formation of small, silt-sized particles that will participate in the dust formation process. 
To study this process and determine the possible level of air dustiness, the physical modelling has been used under laboratory conditions. Physical modelling of the dust formation process was conducted on a laboratory bench, which consisted of an AT-2K-250/500 wind tunnel with non-return-flow and a closed working section, as well as an aspirator with a drive and hoses for sampling and filtration of air. A general view of the stand is presented in Figure 2.

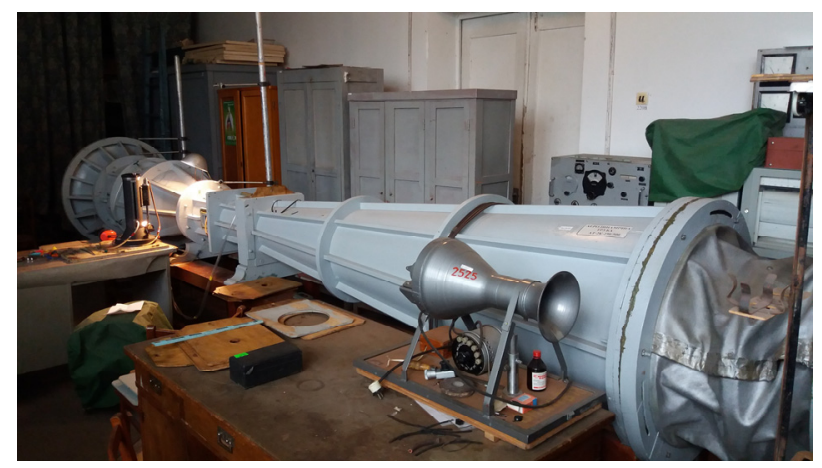

Figure 2. General view of the laboratory stand

The air flow velocity in the working section was adjusted by setting a diffuser with the required diameter. The fan, driven by an electric motor, sucked air through a nozzle with a rectifying grating into the working section, where the mock-up of the bucket with the tube was placed for air sampling. Air was fed through the hoses to the aspirator. Putting into action the aspirator drive, air was sampled from the working area. Then air passed through a previously weighted filter inserted into the sampler. After each sample was taken, the filter was replaced. Weighing the filters before and after the experiments was carried out on a VLR-200 electronic scale, the weighing accuracy of which is $0.05 \mathrm{mg}$.

It is very important during the physical modelling of this process to observe the similarity criteria (Malanchuk, Korniyenko, Malanchuk, \& Khrystyuk, 2016), such as the geometric dimensions of the rock mass particles (Malanchuk, Moshynskyi, Korniienko, \& Malanchuk, 2018) and the air flow velocity and the coefficient of kinematic viscosity of the medium (Falshtynskyi, Dychkovskyi, Saik, \& Lozynskyi, 2014; Sai, Malanchuk, Petlovanyi, Saik, \& Lozynskyi, 2019). When changing the scale of modelling, the difficult problem arises of matching the above factors, so that the result obtained during the modelling could match data that will take place in real conditions (Malanchuk, Moshynskyi, Malanchuk, \& Korniienko, 2018).

Since the dimensions (diameter) of the wind tunnel cannot be changed, and there is a possibility to control the velocity of the air flow, it was decided to take actually obtained material (rock mass) with the granulometric composition characteristic for the conditions of this mine, place it in the mock-up of the bucket and conduct a series of experiments having placed this mock-up in a wind tunnel. At the same time, the air flow velocity in the working section of this tunnel should correspond to the velocity at which ore fines will be blown off from the bucket surface in the shaft.
A small plastic bucket with a diameter in the upper part of $120 \mathrm{~mm}$ and a height of $115 \mathrm{~mm}$ was used as a mock-up of the bucket. This bucket was filled with crushed rock mass, the upper layer of which had a quantity of ore fines corresponding to the actual granulometric composition (i.e., the fractions of $-1+0 \mathrm{~mm}$ ). Ore fines is a potential source of dust formation when moving the bucket along the shaft. Moreover, in the first series of experiments when modelling hoisting a bucket loaded by belt or plate feeder, the amount of the above fine-sized fraction in the upper layer corresponded to the uniform distribution of these fines (i.e., 0.03\%). But, when determining the dust content in the air in case of hoisting a bucket loaded by a vibrating feeder, the amount of fines was reduced to $0.01 \%$, which corresponded to the loaded material segregation set during these studies with this method of the ore mass loading.

When hoisting a bucket from a horizon of $330 \mathrm{~m}$ to the daylight surface (Fig. 1) with a bucket hoisting velocity of $6 \mathrm{~m} / \mathrm{s}$, taking into account the non-uniformity of its movement (acceleration at the beginning and braking at the end of hoisting), the total hoisting time will be about one minute. When modelling the process of blowing off small particles, it can be assumed that the intensity of this process will depend on the time factor: initially, the intensity should be maximized and decrease as the bucket moves towards the shaft collar, since the number and weight of small particles in the upper layer will decrease as a result of their blowing off in the previous section of the shaft. In accordance with this, the dust content in the air should also be changed. Therefore, in order to control this process in time, it was decided to measure the level of air dustiness 3 times and determine it every 20 seconds. When processing the data, air dustiness was determined both at these time intervals and averaged over the entire time of hoisting.

To obtain the predicting data of air dustiness in real conditions, the ratio has been taken into account of the BPSM-4 bucket surface area $\left(2.0 \mathrm{~m}^{2}\right)$ to the area of the bucket mock-up $\left(0.011131 \mathrm{~m}^{2}\right)$, which is $2 / 0.01131 \approx 177$. When the diameter of the working section of the wind tunnel is $0.25 \mathrm{~m}$ and the air flow velocity in it is $10 \mathrm{~m} / \mathrm{s}$, the amount of air passing through it is $0.49 \mathrm{~m}^{3} / \mathrm{s}$. As it is noted earlier, $160.4 \mathrm{~m}^{3} / \mathrm{s}$ of air is supplied along the shaft "Holovnyi" in order to air the mining operations at the mine "Novokostiantynivska". That is, the amount of air under natural conditions will be more than $160.4 / 0.49 \approx 327$ times. Thus, air dustiness in natural conditions will be $327 / 177 \approx 1.85$ times less than in the model.

\section{RESULTS AND DISCUSSION}

When modelling the process of dust formation, the granulometric composition of the rock mass sample provided to us has been determined, the weight of which was about $70 \mathrm{~kg}$. When determining the granulometric composition, the parameters of the large-sized fractions were set by the linear method (i.e., measurements of the geometric dimensions of the separate pieces and their weighting), and the composition of finesized fractions $(-15+0 \mathrm{~mm})-$ by sieve analysis and weighing. For the sieve analysis, sieves with hole sizes of $15,10,7,5,3,2$ and $1 \mathrm{~mm}$ were used. The analysis 
results of the granulometric composition of the sample tested are presented in Table 1.

\section{Table 1. The analysis results of the granulometric composi-} tion of the sample tested

\begin{tabular}{ccc}
\hline $\begin{array}{c}\text { Dimensions of } \\
\text { the factions, mm }\end{array}$ & $\begin{array}{c}\text { Fraction } \\
\text { weight, } g\end{array}$ & $\begin{array}{c}\text { Content of fractions } \\
\text { in the sample, \% }\end{array}$ \\
\hline$-200+100$ & 47050 & 67.640 \\
$-100+50$ & 19554 & 28.130 \\
$-50+15$ & 1880 & 2.700 \\
$-15+0$, & 1063 & 1.530 \\
including: & 813 & 1.170 \\
$-15+10$ & 84 & 0.121 \\
$-10+7$ & 67 & 0.096 \\
$-7+5$ & 31 & 0.045 \\
$-5+3$ & 29 & 0.042 \\
$-3+2$ & 18 & 0.026 \\
$-2+1$ & 21 & 0.030 \\
$-1+0$ & 69512 & 100.000 \\
\hline
\end{tabular}

It can be seen from these data that the content of the $-1+0 \mathrm{~mm}$ fraction, which is a potential source of dust formation when the bucket moves along the shaft, is only $0.03 \%$. With the planned use for hoisting the BPSM-4 bucket, there may be about $7.0-7.5$ tons of rock mass in it, in which there are $2.0-2.3 \mathrm{~kg}$ of fraction $-1+0 \mathrm{~mm}$. But given the factor that such a particle-size distribution as a whole and in the volume of a bucket in particular, has a probabilistic character and can vary within fairly wide range, the actual weight of such a fraction in one bucket can vary from $1.0-1.5$ to $3.5-4.0 \mathrm{~kg}$.

As it was previously noted, the level of air dustiness will also be significantly influenced by the uniformity of ore fines distribution in the volume of a bucket, which in turn will depend on the way of its loading. Since the blowing off dust and small particles will occur exclusively from the upper layer of the rock mass loaded in the bucket, the influence of the way of the ore loading on the ore fines concentration in this layer has been studied. It has been set that when using a plate or belt feeder for loading a bucket, the rock mass is loaded with its more uniform particle-size distribution, which corresponds to its granulometric composition with account of its natural variation around the mean value.

When using a vibrating feeder, segregation of a material by its particle-size is already observed on its surface: small particles move to the lower layer, and much larger fractions predominate on the surface, which in fact do not participate in the dust formation process. About the same pattern of particle-size distribution of material is observed in the upper layer of the rock mass loaded into the bucket: the amount of ore fines in it decreases by $3 . . .4$ times. Taking this into consideration when modelling the dust formation process, it was decided to conduct separate studies of uniform particle-size material distribution, as well as with the lower ore fines concentration in the upper layer, which will be observed when the bucket is loaded by a vibrating feeder.

The data of air dustiness obtained in the model was adjusted with account of the ratio of the BPSM-4 bucket surface area to the area of the bucket mock-up (that is, to account the change in the area from which the small particles will be blown off in real conditions and while modelling, considering this pattern to be straight-line) as well as the actual amount of air that will move per unit of time along the shaft "Holovnyi" and along the wind tunnel when conducting experiments. Such an adjustment will provide an opportunity to obtain data that will most closely correspond to actual conditions and predict the possible level of air dustiness that will occur when hoisting with a bucket the uranium ore to the surface along the above-mentioned shaft.

In accordance with the information provided by the engineering and technical employees of the plant, the shaft "Holovnyi" sectional area is $S_{\text {shaft }}=44 \mathrm{~m}^{2}$, the amount of air supplied through this shaft into the mine is $Q_{\text {shaft air }}=160.4 \mathrm{~m}^{3} / \mathrm{s}$, and the rock mass hoisting by the BPSM-4 bucket is planned to be produced at a velocity of $V_{\text {bucket }}=6 \mathrm{~m} / \mathrm{s}$. Thus, the air flow velocity, with which the ore fines will be blown off from the bucket surface, will be equal to the sum of oncoming velocities of the air supplied through the shaft to the mine from the surface and the velocity of the loaded bucket hoisting.

The air flow velocity along the shaft "Holovnyi" can be determined from the expression:

$V_{\text {shaft air }}=\frac{Q_{\text {shaft air }}}{S_{\text {shaft }}}=\frac{160.4}{44} \approx 37 \mathrm{~m} / \mathrm{s}$.

Thus, the total velocity of the air jet interaction with the surface of the rock mass loaded into the bucket will be:

$V_{\text {air flow }}=V_{\text {shaft air }}+V_{\text {bucket }}=3.7+6.0=9.7 \mathrm{~m} / \mathrm{s}$.

The air flow velocity in the wind tunnel close to the specified velocity, that is $10 \mathrm{~m} / \mathrm{s}$, has been achieved by setting a diffuser with the required diameter $(140 \mathrm{~mm})$. As compared with the required velocity, this one differs by only $3.1 \%$, which, from our point of view, is quite acceptable and will not have a significant influence on the results of this process modelling.

Table 2 presents the results of laboratory studies of air dustiness when hoisting the rock mass with a bucket along the shaft "Holovnyi". Column 4 shows the dust content in the air obtained as a result of measurements in the model, column 6 presents the dust content recalculated with account of the obtained data to real conditions, column 7 shows the ratio of air dustiness to the maximum permissible dust concentration, which for such conditions is $0.6 \mathrm{mg} / \mathrm{m}^{3}$.

Five series of experiments have been conducted, and each of them included 5 tests during which 3 air samples were taken to determine the air dustiness. Table 2 presents the averaged data for each of experiment.

It can be seen from the obtained data that when loading a bucket by a belt or plate feeder, the average air dustiness value during hoisting will almost by 11 times exceed its maximum permissible value. Therewith, as expected, in the first time interval of hoisting $(0-20 \mathrm{~s})$, the excess was maximum (20.7 times), gradually decreesing to 8.1 times in the second time period $(21-40 \mathrm{~s})$, and was minimal at the end of hoisting $(41-60 \mathrm{~s})$ 3.6 times. But in any case, there is a significant excess in the norm of air dustiness, which requires the use of additional measures to reduce it to a permissible level. 
Table 2. Results of laboratory studies of air dustiness when hoisting the rock mass with a bucket

\begin{tabular}{|c|c|c|c|c|c|}
\hline \multirow{2}{*}{$\begin{array}{l}\text { Means for the } \\
\text { bucket loading }\end{array}$} & \multirow{2}{*}{$\begin{array}{l}\text { Rock mass } \\
\text { properties }\end{array}$} & \multirow{2}{*}{$\begin{array}{l}\text { Sampling period } \\
\text { on average for one } \\
\text { cycle of hoisting, } s\end{array}$} & \multicolumn{2}{|c|}{ Air dustiness, $\mathrm{mg} / \mathrm{m}^{3}(S)$} & \multirow{2}{*}{$\begin{array}{l}\text { Exceedance in } \\
\text { permissible air } \\
\text { dustiness, times }\end{array}$} \\
\hline & & & in the model & $\begin{array}{c}\text { recalculated on } \\
\text { natural conditions }\end{array}$ & \\
\hline \multirow{12}{*}{$\begin{array}{l}\text { Belt or plate } \\
\text { feeder }\end{array}$} & \multirow{4}{*}{ Natural humidity } & $0-20$ & 23.00 & 12.40 & 20.70 \\
\hline & & $21-40$ & 9.00 & 4.90 & 8.10 \\
\hline & & $41-60$ & 4.00 & 2.20 & 3.60 \\
\hline & & $0-60$ & 12.00 & 6.50 & 10.80 \\
\hline & \multirow{4}{*}{$\begin{array}{l}\text { Bucket surface } \\
\text { moistened with } \\
\text { water }\end{array}$} & $0-20$ & 0.80 & 0.44 & 0.73 \\
\hline & & $21-40$ & 3.30 & 1.80 & 3.00 \\
\hline & & $41-60$ & 6.70 & 3.60 & 6.00 \\
\hline & & $0-60$ & 3.60 & 2.00 & 3.30 \\
\hline & \multirow{4}{*}{$\begin{array}{l}\text { Surface treated } \\
\text { with aqueous solu- } \\
\text { tion of bischofite }\end{array}$} & $0-20$ & 0.00 & 0.00 & - \\
\hline & & $21-40$ & 0.85 & 0.46 & 0.77 \\
\hline & & $41-60$ & 0.85 & 0.46 & 0.77 \\
\hline & & $0-60$ & 0.57 & 0.31 & 0.52 \\
\hline \multirow{8}{*}{$\begin{array}{l}\text { Vibrating } \\
\text { feeder }\end{array}$} & \multirow{4}{*}{ Natural moisture } & $0-20$ & 6.00 & 3.20 & 5.40 \\
\hline & & $21-40$ & 2.50 & 1.40 & 2.30 \\
\hline & & $41-60$ & 1.00 & 0.54 & 0.90 \\
\hline & & $0-60$ & 3.20 & 1.73 & 2.90 \\
\hline & \multirow{4}{*}{$\begin{array}{l}\text { Bucket surface } \\
\text { moistened with } \\
\text { water }\end{array}$} & $0-20$ & 0.00 & 0.00 & - \\
\hline & & $21-40$ & 0.50 & 0.27 & 0.45 \\
\hline & & $41-60$ & 2.00 & 1.10 & 1.80 \\
\hline & & $0-60$ & 0.80 & 0.44 & 0.73 \\
\hline
\end{tabular}

When moistening with water of the surface of the rock mass loaded into a bucket, the average level of dustiness in the air decreases by more than 3 times (from 6.5 to $2 \mathrm{mg} / \mathrm{m}^{3}$ ), but still will exceed the maximum permissible dust concentration by 3.3 times. However, a change in the level of air dustiness at certain time intervals is of completely different nature: the minimal dustiness value, which is even 1.36 times less than the permissible level, will be at the beginning of the hoisting.

The second time interval has the level of air dustiness already by 3 times higher than its maximum permissible value, and at the end of hoisting, this excess is by 6 times. A logical explanation of the obtained results can be seen in the fact that at the initial stage of hoisting, the capillary forces for the moistened ore mass adhesion was sufficient to bind dust particles, then with increasing time due to the high oncoming air flow velocity, some of the moisture has been weathered out, and as a result of such a surface "dryout", which was only intensified with time, the level of air dustiness increased. Thus, even moistening with water of the surface of a rock mass loaded into a bucket does not, in this case, ensure compliance with the established norms of air dustiness.

Therefore, at the next stage of modelling, the rock mass surface was treated with an aqueous solution of bischofite. With that, there were followed the recommendations presented in the work (Nesterenko, 2001): the density of an aqueous solution of bischofite was about $1.2 \mathrm{~g} / \mathrm{cm}^{3}$, and its specific consumption was about $0.7-0.8 \mathrm{~kg}$ per $1 \mathrm{~m}^{2}$ of the surface to be treated. Due to the fact that the surface treated with such a solution retains moisture for a longer period of time and the adhesion of small particles between themselves and with larger particles increases significantly, a sharp decrease in the level of air dustiness can be seen: at the beginning of hoisting air dustiness is absent, and at the second and third time intervals it is consistently low $(0.75-0.80$ of the maximum permissible dust concentration). In general, for the entire cycle of hoisting, the level of air dustiness is almost by 2 times less than the permissible values.

When using a vibrating feeder for loading a bucket with a low natural moisture content of the ore mass, the level of air dustiness is $3.5-4.0$ times less than when a bucket is loaded by a belt or plate feeder. However, the average value of air dustiness by means of a bucket-type hoisting will still be almost by 3 times higher than its maximum permissible value.

When moistening with water of the surface of the rock mass loaded into a bucket, the level of air dustiness decreases significantly: at the beginning of hoisting, air dustiness is almost absent, increasing at the second and third time intervals to $0.4-0.5$ and $1.5-$ 2.0 from the maximum permissible values, respectively. The average value of air dustiness for the entire cycle of hoisting is by $1.3-1.4$ times less than its maximum permissible values, that is, fully satisfies the requirements of the existing safety norms (Kolosov, Stupnik, \& Kalinichenko, 2014).

\section{CONCLUSIONS}

The studies conducted of the dust formation process when hoisting the uranium ores by means of a bucket along the shaft "Holovnyi" of the mine "Novokostiantynivska", SE "VostGOK" give grounds to recommend using a vibrating feeder for loading the bucket. In this case, high-quality moistening of the surface of the rock mass loaded into a bucket or even its high natural humidity (not less than 4\%) ensures compliance with current air dustiness norms, and it will be $0.7 .0-0.75$ of the maximum permissible dust concentration values under such conditions. However, it should be kept in mind that in the future, with an increase in the depth of mining and, consequently, in the height of hoisting the extracted ore mass to the daylight surface, which will be accompanied by an 
increase in time of hoisting, the high level the natural ore moisture or additional moistening with water of its surface after loading into the bucket will no longer be able to provide a sufficient level of air dustiness reduction.

In the case of using a belt or plate feeder for loading the bucket, it is possible to comply with air dustiness norms under such conditions only by treating the surface of the rock mass loaded into the bucket with the surfactant, such as an aqueous solution of bischofite.

\section{ACKNOWLEDGEMENTS}

The authors express their sincere gratitude to the management of the SE "VostGOK", as well as to the employees of the Industrial Ventilation Laboratory at the State Research Institute for Labour Safety and Ecology in Ore Mining and Metallurgic Industry of Kryvyi Rih National University for their help and assistance in conducting this research.

\section{REFERENCES}

Bondarenko, V., Kovalevs'ka, I., \& Fomychov, V. (2012). Features of carrying out experiment using finite-element method at multivariate calculation of mine massif - combined support system. Geomechanical Processes During Underground Mining - Proceedings of the School of Underground Mining, 7-13. https://doi.org/10.1201/b13157-3

Bondarenko, V., Svietkina, O., \& Sai, K. (2017). Study of the formation mechanism of gas hydrates of methane in the presence of surface-active substances. Eastern-European Journal of Enterprise Technologies, 5(6(89)), 48-55. https://doi.org/10.15587/1729-4061.2017.112313

Falshtynskyi, V., Dychkovskyi, R., Saik, P., \& Lozynskyi, V. (2014). Some aspects of technological processes control of an in-situ gasifier during coal seam gasification. Progressive Technologies of Coal, Coalbed Methane, and Ores Mining, 109-112. https://doi.org/10.1201/b17547-20

Gurin, A.O., Beresnevich, P.V., Nemchenko, A.A., \& Oshmyansky, I.B. (2007). Aerology of mining enterprises. Moscow, Russia: Publishing "Mineral".

Khomenko, O., \& Maltsev, D. (2013). Laboratory research of influence of face area dimensions on the state of uranium ore layers being broken. Naukovyi Visnyk Natsionalnoho Hirnychoho Universytetu, (2), 31-37.

Khomenko, O.Ye. (2012). Implementation of energy method in study of zonal disintegration of rocks. Naukovyi Visnyk Natsionalnoho Hirnychoho Universytetu, (4), 44-54.

Khomenko, O., Sudakov, A., Malanchuk, Z., \& Malanchuk, Ye. (2017). Principles of rock pressure energy usage during underground mining of deposits. Naukovyi Visnyk Natsionalnoho Hirnychoho Universytetu, (2), 35-43.

Kolosov, V., Stupnik, M., \& Kalinichenko, V. (2014). Condition and prospects of Ukrainian mining industry development. Mining of Mineral Deposits, 10(2), 193-197. https://doi.org/10.15407/mining08.02.193

Kovalevs'ka, I., Symanovych, G., \& Fomychov, V. (2013). Research of stress-strain state of cracked coal-containing massif near-the-working area using finite elements technique. Annual Scientific-Technical Collection - Mining of Mineral Deposits, 159-163. https://doi.org/10.1201/b16354-28

Lozynskyi, V., Saik, P., Petlovanyi, M., Sai, K., \& Malanchuk, Z. (2018). Analytical research of the stress-deformed state in the rock massif around faulting. International Journal of Engineering Research in Africa, (35), 77-88. https://doi.org/10.4028/www.scientific.net/jera.35.77

Malanchuk, Y., Moshynskyi, V., Korniienko, V., \& Malanchuk, Z. (2018). Modeling the process of hydromechanical amber extraction. E3S Web of Conferences, (60), 00005. https://doi.org/10.1051/e3sconf/20186000005

Malanchuk, Z.R. (2019). Substantiating parameters of zeolitesmectite puff-stone washout and migration within an extraction chamber. Naukovyi Visnyk Natsionalnoho Hirnychoho Universytetu, (6). Article in press.

Malanchuk, Z., Korniyenko, V., Malanchuk, Y., \& Khrystyuk, A. (2016). Results of experimental studies of amber extraction by hydromechanical method in Ukraine. Eastern-European Journal of Enterprise Technologies, 3(10(81)), 24. https://doi.org/10.15587/1729-4061.2016.72404

Malanchuk, Z., Moshynskyi, V., Malanchuk, Y., \& Korniienko, V. (2018). Physico-mechanical and chemical characteristics of amber. Solid State Phenomena, (277), 80-89. https://doi.org/10.4028/www.scientific.net/ssp.277.80

Nesterenko, O.V. (2001). Wettability of dust with aqueous solutions based on some chlorides. Mining of Ores Deposits, (77), 140-142.

Nesterenko, O.V. (2008). Improving the efficiency of duststripping of highways in quarries. PhD Thesis. Kryvyi Rih, Ukraine: Kryvyi Rih Technical University.

Pismennyi, S.V. (2014). Development of folding structural deposits of rich ores by chamber development systems. Mining Bulletin: Scientific and Technical Collection, (97), 3-7.

Pysmennyi, S., Brovko, D., Shwager, N., Kasatkina, I., Paraniuk, D., \& Serdiuk, O. (2018). Development of complex structure ore deposits by means of chamber systems under conditions of the Kryvyi Rih iron ore field. Eastern-European Journal of Enterprise Technologies, 5(1(95)), 33-45. https://doi.org/10.15587/1729-4061.2018.142483

Safety rules for the development of deposits of ore and nonmetallic minerals underground. (2017). Kyiv, Ukraine: Fort.

Sai, K., Malanchuk, Z., Petlovanyi, M., Saik, P., \& Lozynskyi, V. (2019). Research of thermodynamic conditions for gas hydrates formation from methane in the coal mines. Solid State Phenomena, (291), 155-172. https://doi.org/10.4028/www.scientific.net/SSP.291.155

Stupnik, N.I., Kalinichenko, V.A., \& Kalinichenko, Ye.V. (2018). The study of the stress-strain state of the massif in mining uranium at "Vostgok" deposits. Kyiv, Ukrain: Publishing House "St. Ivan Rylskyi".

Stupnik, N.I., Kalinichenko, V.A., Fedko, M.B., \& Kalinchenko, Ye.V. (2018). Technology of underground block leaching at underground mines of "Vostgok". Petrosani, Romania: Publishing of Petrosani Universitatas..

Stupnik, N.I., Kalinichenko, V.A., Fedko, M.B., \& Mirchenko, Ye.G. (2013a). Prospects for the use of non-trotylous explosives in mines with underground mining of minerals. Naukovyi Visnyk Natsionalnoho Hirnychoho Universytetu, (1), 44-49.

Stupnik, N.I., Kalinichenko, V.A., Fedko, M.B., \& Mirchenko, Ye.G. (2013b). The influence of the stress-strain state of the rock mass on the technology of breaking uranium ores. Naukovyi Visnyk Natsionalnoho Hirnychoho Universytetu, (2), 11-16.

Tarasyutin, V.M. (2015). Geotechnology features of high quality martite ore from deep mines of Kryvyi Rih basin. Naukovyi Visnyk Natsionalnoho Hirnychoho Universytetu, (1),54-60.

Tkachuk, K.N., Tkachuk, K.K., \& Gurin, Yu.A. (2011). Labor protection. Kryvyi Rih, Ukraine: Publishing Center of Kryvyi Rih Technical University.

Vladyko, O., Kononenko, M., \& Khomenko, O. (2012). Imitating modeling stability of mine workings. Geomechanical Processes During Underground Mining - Proceedings of the School of Underground Mining, 147-150. https://doi.org/10.1201/b13157-26 


\section{ДОСЛІДЖЕННЯ ПРОЦЕСУ ПИЛОУТВОРЕННЯ ПРИ БАДДСВОМУ ПІДЙОМІ УРАНОВИХ РУД}

\section{М. Ступнік, В. Калініченко, М. Федько, О. Калініченко, В. Пухальський, Б. Кривохін}

Мета. Визначення можливого рівня запиленості повітря при баддєвому підйомі уранових руд по стволу "Головний” Новокостянтинівської шахти ДП “СхідГЗК”.

Методика. Для визначення рівня запиленості повітря було використано фізичне моделювання даного процесу в лабораторних умовах. Фізичне моделювання процесу пилоутворення було здійснено на лабораторному стенді, який складався з аеродинамічної труби АТ-2К-250/500 з незамкнутим потоком і закритою робочою частиною, а також аспіратора з приводом і шлангами для відбору повітря та його фільтрації. Для моделювання визначався гранулометричний склад: параметри великих за розмірами фракцій - лінійним методом (тобто вимірами геометричних розмірів окремих кусків та їх зважуванням), а склад дрібних фракцій $(-15+0$ мм) - ситовим аналізом і зважуванням.

Результати. Визначено гранулометричний склад гірської маси, яку планується видавати баддєвим підйомом по стволу "Головний", а також проведено моделювання процесу пилоутворення на лабораторному стенді. Встановлено, що на рівень запиленості повітря при баддєвому підйомі гірської маси істотний вплив чинитиме ії вологість або додаткове зв'язування рудного дріб'язку в верхньому шарі обробкою поверхнево-активними речовинами, а також рівномірність розподілу цього дріб'язку в об'ємі бадді, яка, в свою чергу, буде залежати від способу іiї завантаження. Рекомендовано використання для завантаження бадді вібраційного живильника. При цьому, достатня природна вологість гірської маси (більше 4\%) забезпечує рівень запиленості повітря, що видається, нижче нормативних показників.

Наукова новизна. Встановлено, що запиленість повітря залежить від вологості гірської маси й при наявності вологи у руді понад $4 \%$ забезпечує зниження рівня запиленості повітря до $0.40-0.45 \mathrm{mr} / \mathrm{M}^{3}$, що становить $0.67-0.75$ від існуючої норми запиленості для таких умов.

Практична значимість. Отриманий результат підтверджує можливість використання баддєвого підйому по стволу “Головний” на денну поверхню видобутих на шахті “Новокостянтинівська” уранових руд (при дотриманні запропонованих рекомендацій) без перевищення існуючих норм запиленості повітря, що подається в шахту.

Ключові слова: баддєвий підйом, запиленість, повітря, заходи щюдо пилопригнічення, руда

\section{ИССЛЕДОВАНИЕ ПРОЦЕССА ПЫЛЕОБРАЗОВАНИЯ ПРИ БАДЬЕВОМ ПОДЬЕМЕ УРАНОВЫХ РУД}

\section{Н. Ступник, В. Калиниченко, М. Федько, Е. Калиниченко, В. Пухальский, Б. Кривохин}

Цель. Определение возможного уровня запыленности воздуха при бадьевом подъеме урановых руд по стволу “Главный” Новоконстантиновской шахты ГП “ВостГОК”.

Методика. Для определения уровня запыленности воздуха было использовано физическое моделирование данного процесса в лабораторных условиях. Физическое моделирование процесса пылеобразования было произведено на лабораторном стенде, который состоял из аэродинамической трубы АТ-2К-250/500 с незамкнутым потоком и закрытой рабочей частью, а также аспиратора с приводом и шлангами для отбора воздуха и его фильтрации. Для моделирования определялся гранулометрического состав: параметры больших по размерам фракций - линейным методом (т.е. замерами геометрических размеров отдельных кусков и их взвешиванием), а состав мелких фракций $(-15+0$ мм) - ситовым анализом и взвешиванием.

Результаты. Определен гранулометрический состав горной массы, которую планируется выдавать бадьевым подъемом по стволу “Главный”, а также проведено моделирование процесса пылеобразования на лабораторном стенде. Установлено, что на уровень запыленности воздуха при бадьевом подъеме горной массы существенное влияние будет оказывать ее влажность или дополнительное связывание рудной мелочи в верхнем слое обработкой поверхностно-активными веществами, а также равномерность распределения этой мелочи в объеме бадьи, которая, в свою очередь, будет зависеть от способа ее загрузки. Рекомендовано использование для загрузки бадьи вибрационного питателя. При этом, достаточная естественная влажность горной массы (более 4\%) обеспечивает уровень запыленности выдаваемого воздуха ниже нормативных показателей.

Научная новизна. Установлено, что запыленность воздуха зависит от влажности горной массы и при наличии влаги в руде более $4 \%$ обеспечивает снижение уровня запыленности воздуха до $0.40-0.45 \mathrm{m \Gamma} / \mathrm{M}^{3}$, что составляет $0.67-0.75$ от существующей нормы запыленности для таких условий.

Практическая значимость. Полученный результат подтверждает возможность использования бадьевого подъема по стволу “Главный” на дневную поверхность добытых на шахте “Новоконстантиновская" урановых руд (при соблюдении предложенных рекомендаций) без превышения существующих норм запыленности подаваемого в шахту воздуха.

Ключевые слова: бадьевой подъем, запыленность, воздух, мероприятия по пылеподавлению, руда

\section{ARTICLE INFO}

Received: 7 March 2019

Accepted: 21 August 2019

Available online: 3 September 


\section{ABOUT AUTHORS}

Mykola Stupnik, Doctor of Technical Sciences, Rector of the Kryvyi Rih National University, 11 Matusevycha St, 50027, Kryvyi Rih, Ukraine. E-mail: kpv_p@hotmail.com

Vsevolod Kalinichenko, Doctor of Technical Sciences, Head of the Department of Underground Mining of Mineral Deposits, Kryvyi Rih National University, 11 Matusevycha St, 50027, Kryvyi Rih, Ukraine. E-mail: vsevolod921@mail.ru

Mykhailo Fedko, Candidate of Technical Sciences, Associate Professor of the Department of Underground Mining of Mineral Deposits, Kryvyi Rih National University, 11 Matusevycha St, 50027, Kryvyi Rih, Ukraine. E-mail: fedkomb@i.ua

Olena Kalinichenko, Candidate of Economic Sciences, Associate Professor of the Department of Underground Mining of Mineral Deposits, Kryvyi Rih National University, 11 Matusevycha St, 50027, Kryvyi Rih, Ukraine. E-mail: elenakalinichenko_v@,mail.ru

Viktor Pukhalskyi, Candidate of Technical Sciences, Engineer in-Chief of the SE "Eastern Ore Dressing Complex" (SE "VostGOK”), 2 Horkoho St, 52210, Zhovti, Vody, Ukraine. E-mail: vostgok@email.dp.ua

Borys Kryvokhin, Chief of Mining Department of the SE "Eastern Ore Dressing Complex" (SE "VostGOK"), 2 Horkoho St, 52210, Zhovti, Vody, Ukraine. E-mail: smi@vostgok.dp.ua 